\title{
Enclave Governance and Transnational Labour Law - A Case Study of Chinese Workers on Strike in Africa
}

\author{
Yifeng Chen \\ Associate Professor, Peking University, China \\ yifeng.chen@pku.edu.cn \\ Ulla Liukkunen \\ Professor, University of Helsinki, Finland \\ ulla.liukkunen@helsinki.fi
}

\begin{abstract}
This article examines deficits in the current legal framework of posted workers in a global setting through a case study involving Chinese posted workers striking in Equatorial Guinea. Posting highlights the challenges that economic globalisation and transformation of the labour market pose to labour law. As a phenomenon whose normativity is deeply embedded in the cross-border setting where it occurs, posting should profoundly affect the transnational labour law agenda. The emergence of transnational labour law should be seen from the perspective of reconceptualising existing normative regimes in the light of an underpinning transnationality and sketching the architecture for the normative edifice of transnational labour protection. The transnational legal context under scrutiny calls for a wider normative framework where the intersections between labour law, international law and private international law are taken seriously. Global protection of posted workers should be a featured project on the transnational labour law agenda.
\end{abstract}

\section{Keywords}

international law - labour law - transnational labour law - private international law posted workers - globalisation 


\section{Introduction}

Economic globalisation has made transnational movement of workers a growing phenomenon. Cross-border posting of workers is often accessory to transnational provision of trade in services, or sometimes part of global human resources management in a multinational enterprise for its interaction with subsidiaries and affiliates. The use of posted workers is justified on the basis of business autonomy or commercial necessity, and the labour dimension of the posted workers phenomenon is often overshadowed by a business-oriented approach. Competing regulatory approaches emerge, also within a trade law perspective and a labour law perspective, in determining the legal status of posted workers, which in turn has affected development of rules on jurisdiction and applicable law. ${ }^{1}$

So far the discussion of labour protection in posting-of-workers cases has been strikingly European despite its global relevance. ${ }^{2}$ Considerable debate has been triggered by the landmark judgment of the European Court of Justice (CJEU) in the Laval case. ${ }^{3}$ The social dimension of the European Union has given way to the rationale of economic liberation, with priority given to EU fundamental economic freedoms in the European integration process. ${ }^{4}$ The interpretation by the CJEU of the EU Directive on Posted Workers ${ }^{5}$ has

1 The regulatory approach of the European Union is highly illustrative in this regard. The regulatory power of the host state on posted workers has been construed narrowly against the foundational economic principles of the EU, i.e., freedom to provide services. See e.g., T. Novitz, 'Evolutionary Trajectories for Transnational Labour Law: Trade in Goods to Trade in Services?', 67 Current Legal Problems (2014) pp. 239-271.

2 In Europe, the posting phenomenon gained relevance within the EU and posted workers were regarded as a particular category of workers different from those moving on their own to work in another EU Member State, first via European Court of Justice (hereinafter CJEU) judgments that set a specific legal regime for workers posted from one EU Member State to another, and later via the Posted Workers Directive of 1996.

$3 C_{-341 / 05}$, Laval un Partneri Ltd v. Svenska Byggnadsarbetareförbundet, Svenska Byggnadsarbetareförbundets avdelning 1, Byggettan, Svenska Elektrikerförbundet.

4 See M. Freeland and J. Frassl (eds.), Viking, Laval and Beyond (Hart Publishing, Oxford, 2014). See also S. Deakin, 'Regulatory Competition after Laval', 10 Cambridge Yearbook of European Legal Studies (2008) pp. 581-6og; U. Liukkunen, 'Collision Between the Economic and the Social What Has Private International Law Got to Do with It?', in P. Letto-Vanamo and J. Smits (eds.), Coherence and Fragmentation in European Private Law (Sellier, Munich, 2012) pp. 125-150.

5 Directive 96/71/EC of the European Parliament and of the Council of 16 December 1996 concerning the posting of workers in the framework of the provision of services. See also Directive 2014/67/EU of the European Parliament and of the Council of 15 May 2014 on the enforcement of Directive $96 / 71 / \mathrm{EC}$ concerning the posting of workers in the framework of 
highlighted the individualistic approach of the Directive. This approach has been criticised for its adverse effect on the autonomy of collective bargaining systems in countries with a strong collective labour law tradition and industrial relations model, such as Sweden. ${ }^{6}$

The EU internal market has been designed primarily to facilitate the exercise of fundamental economic freedoms. At the same time, there is an understanding that the business autonomy involved needs to be balanced by labour protection. However, the juxtaposition between employee protection and economic interests has proved to be a dilemma that reaches to the core of the objective of developing a sustainable European social model. With the Posted Workers Directive, fundamental economic freedoms as key pillars of the internal market are placed not only against fundamental rights of workers but also against the very foundations of national labour market systems that are required to adjust to the adopted regulatory framework. ${ }^{7}$

In the EU, discussion has focused on posting of workers as a European phenomenon. The EU provides different legal frameworks for different kinds of cross-border work, and the regulatory framework for posting applies within the free provision of services. Accordingly, posted workers are not entitled to full protection of the labour law regulation of the host state, which individuals crossing borders in the framework of free movement of workers enjoy in the Union. The Posted Workers Directive does not harmonise the substantive legislation of the EU Member States but determines the 'hard core' of the terms and conditions of employment under host state law - such as minimum wages, working hours and annual holidays - that becomes applicable to workers posted to that state for temporary work.

European discussion lays emphasis on settling legal questions that relate to determining the sphere of applicable host country rules as well as difficulties that arise with that and enforcement of the applicable rules. The line of interpretation by the CJEU on the determination and application of labour standards in the case of posting has prompted critical voices. Behind the CJEU jurisprudence on posting lie deeper constitutional questions that relate

the provision of services and amending Regulation (EU) No 1024/2012 on administrative cooperation through the Internal Market Information System ('the IMI regulation').

6 See J. Malmberg and T. Sigeman, 'Industrial Actions and EU Economic Freedoms: The Autonomous Collective Bargaining Model Curtailed by the European Court of Justice', 45:4 Common Market Law Review (2008) pp. 1115-1146.

7 See Liukkunen, supra note 4, p. 143. 
to problems with the power balance between the EU Member States and the Union. ${ }^{8}$

As the regulatory model of the Posted Workers Directive is based on the application of host state rules in questions specified by the Directive, and states are allowed to enlarge the 'hard core' list of applicable rules only on certain conditions, the level of protection provided by host state law to posted workers remains limited. It is in practice difficult to draw dividing lines of labour protection required by the regulatory approach of the Directive. Moreover, the Directive lacks a clear and precise account of the possibilities to enlarge the list on the basis of necessary protection.

Criticism also surrounds the unilateral application of host state rules set out by the Directive, as states in their role of home states are not obliged to ensure the application of 'hard core' host state rules to posted workers. The recent EU Enforcement Directive aims at making the Posted Workers Directive more effective. ${ }^{9}$ Importantly, although the focus is on the internal market of the Union, companies posting workers to an EU Member State from third states must also follow the rules on the application of host state law set out in the Posted Workers Directive. ${ }^{10}$ However, this does not remove problems of the regulatory approach that emphasises unilateral application of host state law and authorises selective application of labour standards.

Existing legal literature on posted workers appears to have two important limitations. The first is the absence of accounts of the subjective experience of posted workers in the field of legal research. ${ }^{11}$ Posted workers are often depicted as beneficiaries of better economic opportunities in their host countries and as foreign workers who bring with them the highlighted risk of social dumping to the labour markets of host countries. This narrative tends to overlook the fact that, despite regulatory efforts, in reality posted workers often suffer from denial of labour protection and lack of access to an effective dispute

8 See, e.g., C. Barnard, 'More Posting', 43 Industrial Law Journal (2014) p. 210.

9 See Directive 2014/67/EU of the European Parliament and of the Council of 15 May 2014 on the enforcement of Directive 96/71/EC concerning the posting of workers in the framework of the provision of services and amending Regulation (EU) No 1024/2012 on administrative cooperation through the Internal Market Information System ('the IMI Regulation').

10 However, the Posted Workers Directive does not apply to merchant navy undertakings as regards seagoing personnel.

11 Useful research has been done outside legal studies on analyses about workers' experience, though. See, e.g., E. Caro, L. Berntsen, N. Lillie and I. Wagner, 'Posted Migration and Segregation in the European Construction Sector', 41 Journal of Ethnic and Migration Studies (2015) pp. 1600-1620. 
settlement mechanism. Secondly, there has been a striking lack of interest in developing a global approach to the protection of posted workers. Most of the scholarly discussion focuses on European law and practice, or orients towards cross-border workers in general. Even the ILO has paid very little attention to the issue of workers crossing borders outside the scope of two migrant workers conventions. ${ }^{12} \mathrm{~A}$ considerable normative and intellectual vacuum remains open from the perspective of developing a global mechanism for protection.

The legal subjectivity of posted workers is often denied recognition or severely constrained in a transnational context. This article explores the legal position of posted workers on foreign soil where their labour rights are often vague, uncertain, vulnerable, unenforceable, and even denied in reality. Disputes between employer and workers may occur on a broad range of issues, such as remuneration, working time, working conditions, workplace health, accommodation, food quality, management style, and so on. Workplace conflicts are often exacerbated due to lack of effective cross-border dispute settlement mechanisms to enforce the rights of workers.

This article offers a case study of Chinese posted workers striking in Equatorial Guinea. ${ }^{13}$ It examines deficits in the current legal framework of posting in a global setting. In the case under scrutiny, labour disputes escalated into radical forms of conflict, unauthorised strikes and physical violence towards workers. Unauthorised industrial action disrupted the public order of the host country. As a consequence of the incidents, imminent questions arose as to whether certain labour rights of workers could be extraterritorially recognised and enforced. Cross-border posting presents enormous regulatory challenges, largely owing to failure by the existing normative framework of international labour standards to acknowledge the legal subjectivity of posted workers. This study demonstrates that posting as a global phenomenon involves complicated questions of transnational social dumping that relate to different kinds of subcontracting chains and constantly changing ways of global business operation.

12 See Convention concerning Migration for Employment (Revised), 1949 (No. 97), and Convention concerning Migrations in Abusive Conditions and the Promotion of Equality of Opportunity and Treatment of Migrant Workers, 1975 (No. 143).

13 For an interesting study on Chinese posted workers in Romania, see C. Xiao and Z. Han, “海外中国劳工群体利益表达的困境 - 冲突与解决- - 以罗马尼亚中国 工人劳务纠纷为例 (The Dilemma, Conflicts and Solutions for the Expression of Group Interests of Overseas Chinese Laborers - With Reference to the Case of a Labour Dispute involving Chinese Workers in Romania)', 3 东南亚研究 (Southeast Asian Studies) (2014) pp. 54-61. 
The article presents a case study of enclave governance in transnational economic activities and purports to explore the implications of enclave governance for transnational labour protection. To a large extent, the operation of business and the mode of industrial relations may constitute a selfcontained enclave on foreign soil. ${ }^{14}$ In certain cases, a workplace might turn into a self-contained enclave with its own norms, culture, authority and structure of operation when it is socially segregated and authoritatively managed. This operation of enclaves causes fundamental challenges to the territorial assumption of national labour law as well as its effectiveness..$^{15}$ There is a need for more critical reflections on the territoriality of labour law as well as possible reconstruction at the time of increasing globalisation. Arguably, posting of workers, as a phenomenon whose normativity is deeply embedded in the cross-border setting where it occurs, should profoundly affect the transnational labour law agenda. The legal challenges of addressing cross-border posting highlight an increasing need to take the interconnections between public international law, international labour law and private international law more seriously in the global setting. ${ }^{16}$ Importantly, they further reveal certain structural limits of the core labour standards movement propelled by the ILO since the late 1990s. ${ }^{17}$

14 The term enclave is used in a metaphorical rather than a normative sense. An enclave in international law technically means "an isolated part of the territory of a State, which is entirely surrounded by the territory of only one foreign State", see T. H. Irmscher, 'Enclaves', in Max Planck Encyclopedias of International Law, <opil.ouplaw.com/view/10.1093/ law:epil/978019923169o/law-978019923169o-e1037?rskey=ngnOhE\&result=1\&prd=EPIL >, visited on 9 June 2019. Sociologists also use the term enclave in a loose sense to refer to certain self-contained social life based on ethnicity and territoriality. For example, enclave is applied to describe Chinatowns in the United States, see J. Lin (ed.), Reconstructing Chinatown: Ethnic Enclave, Global Change (University of Minnesota Press, Minneapolis, MN, 1998).

15 Yet it is useful to highlight that the Westphalian assumption that sovereign states would exercise absolute and effective control within their respective territories is only a political construction rather than a reality. Useful reflections on this subject can be found in $\mathrm{M}$. Kuijer and W. Werner (eds.), Netherlands Yearbook of International Law 2016: The Changing Nature of Territoriality in International Law (T.M.C. Asser Press, The Hague, 2017).

16 See A. Mills, The Confluence of Public and Private International Law:Justice, Pluralism and Subsidiarity in the International Constitutional Ordering of Private Law (Cambridge University Press, Cambridge, 2009); see also J. Stevenson, 'The Relationship of Private International Law to Public International Law', $5^{2}$ Columbia Law Review (1952) p. 561.

17 Core labour standards have been defined by the ILo Declaration on Fundamental Rights and Principles at work, adopted 18 June 1998. The eight ILO 'core' or 'fundamental' Conventions are: the Forced Labour Convention No. 29, the Freedom of Association and 
As the case study limits itself to conflicts between Chinese posted workers and an overseas Chinese company, the article does not look into problems of labour protection between Chinese investors and their foreign employees. ${ }^{18}$ This subject would deserve further research in view of China's increasing overseas investment and growing number of locally employed workers. ${ }^{19}$ However, the case study here opens a useful window to understanding how Chinese and other foreign companies might organise workplaces and apply relevant labour standards in the transnational context of posting.

Immediately after China's adoption of the reform and opening-up policy in the late 1970s, international mobility of Chinese workers started to prosper. In the early years, international labour cooperation involved recruitment of Chinese workers by foreign employers to work in foreign countries through an authorised labour intermediary. ${ }^{20}$ In recent decades, another form of labour mobility, in the shape of cross-border posting of Chinese workers, has become increasingly important. As the Chinese government formally pursued

Protection of the Right to Organise Convention No. 87, the Right to Organise and Collective Bargaining Convention No. 98, the Equal Remuneration Convention No. 100, the Abolition of Forced Labour Convention No. 105, the Discrimination (Employment and Occupation) Convention No. 111, the Minimum Age Convention No. 138, and the Worst Forms of Child Labour Convention No. 182.

18 Interesting work in this regard has been done, for example, by C. K Lee, 'Raw Encounters: Chinese Managers, African Workers and the Politics of Casualization in Africa's Chinese Enclaves', 199 The China Quarterly (2009) pp. 647-666.

19 According to the statistics, by the end of 2017 Chinese companies had employed 708, 000 local workers, out of which 346, 200 were in Africa and 345, 200 in Asia. See Ministry of Commerce \& China International Contractors Association of the People's Republic of China, 中国对外劳务合作发展报告 2017-2018 (Annual Report on China International Labour Cooperation 2017-2018), 6 November 2018, <www.fdi.gov.cn/180oooo121_35_2353_o_7. html >, visited on 9 June 2019, p. 13 .

20 This form of international labour mobility remains an important part of China's international economic cooperation. According to the statistics of the Ministry of Commerce, 300,000 workers were sent abroad through this channel in 2017. See Ministry of Commerce of the People's Republic of China Department of Outward Investment and Economic Cooperation, 2017 年我国对外劳务合作业务简明统计 (The Concise Statistics of China's Foreign Labour Service Cooperation in 2017), 16 January 2018, <hzs.mofcom. gov.cn/article/date/201801/20180102699457.shtml>, visited on 6 June 2019. 
its 'go global' strategy in $2001^{21}$ in tandem with China's accession to the WTO, Chinese companies began actively to engage in contracting infrastructure and construction projects abroad. Within the framework of the overseas posting of workers for international projects, workers remain as employees of Chinese companies.

According to official statistics from the Chinese Ministry of Commerce, by the end of 2017 China had around 979,00o Chinese workers working abroad through official channels. ${ }^{22}$ Among them, almost half were posted workers. It is recorded that in 2016, altogether 230,000 Chinese workers were posted abroad by Chinese companies for overseas contracted projects. This figure is a considerable jump from a mere 55,612 posted workers in $2000 .^{23}$ The rapid increase in posted workers is a direct result of the growing involvement by Chinese companies in global construction projects after the 2000s. ${ }^{24}$

On 28 March 2008, the Chinese Ministry of Foreign Affairs put a notice on its webpage reporting a violent clash between Chinese workers on strike and local police in Mongomo, Equatorial Guinea. Two Chinese workers were killed and four injured. ${ }^{25}$ The root cause of the tragedy was a dispute between

21 National People's Congress of the People's Republic of China, 中华人民共和国国民 经济和社会发展第十个五年计划纲要 (Tenth Five-Year Plan for National Economic and Social Development of the People's Republic of China), 15 March $2001<$ www.ndrc .gov.cn/fzgggz/fzgh/ghwb/gjjh/200709/Po20070912638588995806.pdf>, visited on 9 June 2019.

22 Ministry of Commerce of the People's Republic of China Department of Outward Investment and Economic Cooperation, supra note 20.

23 Editorial Board of the China Foreign Economic and Trade Annual (ed.), Annals of China External Foreign Economic Relations and Trade Statistics (China Foreign Economic and Trade Press, Beijing, 2001) p. 746.

24 Inside China the number of foreign workers is also increasing steadily. China does not make a distinction between posted workers and other types of foreign workers. The employment of foreigners in China is governed by the Provisions on the Employment of Foreigners jointly issued by the Ministry of Labour, the Ministry of Public Security, the Ministry of Foreign Affairs and the Ministry of Foreign Trade and Economic Cooperation on January 22, 1996. A permit system was introduced and the employer is responsible for filing a work permit application for the employee. A work permit can be valid for five years at the maximum and can be renewed on the application of the employer. As for regulation of employment contracts, Chinese laws on minimum wages, rest and holidays, and dispute settlement apply.

25 Ministry of Foreign Affairs of the People's Republic of China, 我劳务人员在赤几罢 工引发冲突事件 (Strikes by Chinese Labourers Triggered Conflict in Equatorial Guinea), 2008, <www.fmprc.gov.cn/chn//gxh/cgb/zcgmzysx/fz/1206_7/xgxw/t419058.htm>, visited on 6 June 2019 . 
Chinese posted workers and their Chinese employer, which was a subcontractor for a local housing project in Equatorial Guinea. The case will be studied to illustrate some general problems of labour protection that are typical of crossborder posting. The analysis does not touch upon questions that relate to Chinese companies' labour practices toward their African workers, labour issues in China's African policy, or China's African policy as a labour market phenomenon more generally. ${ }^{26}$ The findings of the case draw attention to the isolation of posted workers from the surrounding community and how this segregation affects their position as employees and thus spells out the labour question in a transnational setting. ${ }^{27}$ On a more general level, the findings speak for the need to develop a regulatory framework for posted workers in a global setting.

\subsection{Terms of Posting}

Jianyu Overseas Development Company Limited ('Jianyu') was established by its holding company, Weihai Construction Group in Shandong Province, China, to develop overseas business. A series of housing projects in Equatorial Guinea were contracted to a Chinese company, Dalian International Cooperation Company Limited. Jianyu, which was a subcontractor to one of those housing projects, recruited two groups of workers. The first group was directly recruited from Weihai Municipality in Shandong Province where the subcontractor was registered. The second, recruited through a labour intermediary named Huanyu Jiangong Economic Cooperation Company Limited ('Huanyu'), consisted of more than one hundred workers from Donghai County in Jiangsu Province, a neighbouring province.

Most of the workers recruited from Donghai County were local peasants attracted by minimum monthly pay of USD 540 and a total of CNY 90,000 to 110,000 income for a two-year posting, as advertised by the intermediary, Huanyu. This amount was much better than income from farm work in China. The workers were required to pay CNY 20,000 to Jianyu as a performance deposit and another CNY 3,00o to Huangyu as a lump-sum intermediary and administration fee. In the employment contracts, a piecework remuneration system was adopted. The contracts further stipulated that specific standards of remuneration were to be decided by the project management on the basis

26 See A. Oshodi, 'Between the Dragon's Gift and its Claws: China in Africa and the (Un)Civil Fostering of ILO's Decent Work Agenda', in A. Marx, J. Wouters, G. Rayp and L. Beke (eds.), Global Governance of Labour Rights: Assessing the Effectiveness of Transnational Public and Private Policy Initiatives (Edward Elgar, Cheltenham, 2015) pp. 190-208.

27 See A. Somek, 'The Social Question in a Transnational Context', 39 LSE Europe in Question Discussion Paper Series (2011) p. 6. 
of local circumstances and the actual amount of wages was to be sorted out at the end of each month.

In practice, the employer's practice concerning wages did not conform to the contractual terms. Workers were upset by the failure of Jianyu to publish their salary on a monthly basis. In October 2008, having worked for five months, they received information from Jianyu about their salaries for the first five months, with the monthly income ranging from USD 600-700. They were paid at the rate of USD 300 per month, with the rest being withheld by Jianyu. Irrespective of this violation of contracts by the employer, workers were nevertheless satisfied with the salary scale.

In February 2009, Jianyu for the second time published the salaries of workers, this time from the previous four months. Workers noted that the salary scale was stable, roughly the same as in the previous month. However, this raised much concern among them, as the exchange rate of US dollars against the Chinese yuan had dramatically dropped by 8.85 per cent within a one-year period. ${ }^{28}$ Since the US dollar was the agreed currency for remuneration, the workers were aware of their shrinking income. The drop in the exchange rate was particularly disturbing as Jianyu still withheld more than half of their salary.

\subsection{Workers on Strike on Foreign Soil}

Already in early March 2007, some workers started to approach the project manager requesting Jianyu to publish the salary on a monthly basis. When the workers were informed of the company's refusal, about 60 workers from Donghai County refused to work and other workers from Weihai Municipality joined in the action. The workers then requested Jianyu to publish the salary on a monthly basis and to compensate the loss caused by the falling exchange rate. Alternatively, if Juanyu was unwilling to compensate the loss arising from the exchange rate, the company should pay the salary in full every month. Both requests met with an indifferent and abusive attitude from the company. Then the workers were left on work stoppage strike, but in a peaceful manner.

The situation became increasingly confrontational when the local police became involved at the invitation of the management. On 20 March, about 15 Guinean policemen came to the workers' dormitory and urged them to return to work. Workers were told by the police that the strike was against local law. Under the law of Equatorial Guinea, unauthorised strikes were strictly prohibited. The workers tried to explain the factual background and then the police left. However, the workers were irritated at the fact that the management had

28 The exchange rate dropped from 7.68 in May 2007 to 7.16 in February 2008 and 7 in April 2008. 
colluded with the local police authority to suppress their rightful demands. On 24 March, the manager came to the dormitory together with armed local policemen. The management named 13 workers, whom the policemen tried to take away. All 13 workers were from Donghai County and were reported to have had some personal issues with the manager. The workers resisted police action physically. The situation was chaotic and the police fired a warning shot. Failing to take the workers, the police withdrew.

About 40 policemen came again on the second day. Through an interpreter, they announced the prohibition of the strike according to the law of Equatorial Guinea and urged the workers back to work. The workers insisted on fulfilment of contractual obligations by the employer as a pre-condition for their return to work. As the police and the workers were not able to reach an agreement after a short discussion, the policemen started to arrest workers and dragged them to their cars. The workers again resisted, standing hand in hand and trying to push the police out of the dormitory yard. Some workers picked up sticks and stones. According to the recollection of one worker, a fellow worker threw a stone at the police, and policemen then opened fire with their rifles. Two Chinese workers were killed and four were injured. The rest of the workers were taken into custody.

The Chinese government and its embassy in Equatorial Guinea quickly responded to the tragedy. The Chinese government urged the Equatorial Guinean government to conduct a thorough investigation. The consul for economic affairs at the Chinese embassy visited the workers in custody. At the end of March, the Chinese government dispatched a working group to Equatorial Guinea to handle the matter. The group consisted of altogether 28 persons from the Ministry of Foreign Affairs, the Ministry of Commerce and local government representatives from the provinces where the posted workers came from. After days in custody the arrested workers were directly transported to the airport and deported. In early April, the first group of about 180 workers landed in Shanghai, together with two dead bodies. Two days later, another 171 workers returned to China.

\subsection{Labour Rights Involved}

A number of important labour rights are at stake in the case. A primary evaluation raises the question on what legal basis these rights may be grounded, measured and evaluated. Yet this raises complicated questions of what laws are to be applied and how the applicable law should be determined. As Equatorial Guinea is the place of performance of the employment contract, and the place where the strike occurred, primarily the labour legislation of Equatorial Guinea would be a natural point of departure in terms of the applicable law in this case, 
especially with regard to mandatory rules. However, Chinese labour law might also be relevant as Chinese labour legislation could turn out to be applicable as a result of choice of law. In terms of identification and implementation of labour rights in the case, the applicable law might turn out to be fragmented and vague, depending on the categories and categorisations of relevant rights, and the place of the court seized of the case. Additionally, private international rules which could be vague and unclear - applied by the competent court would have a significant impact on the outcome. Moreover, the ILO conventions are also relevant for measuring compliance with labour rights and protection here. Equatorial Guinea has ratified all eight fundamental labour conventions of the ILO in addition to another six rather technical conventions, ${ }^{29}$ while China has ratified six fundamental labour conventions. The labour rights that are discussed in this case study are more based on the general principles and common practice of states than any precise lex causae.

First of all, the case concerns the right to remuneration to be paid fully and timely. The contracts were based on a piecework system so that the salary depended on the actual amount of work that had been performed by each worker. The calculation was usually made at the end of each month and afterwards workers were to be informed of the exact amount of salary.

Secondly, the employer had illegally taken performance deposits from the workers. Jianyu charged each worker $\mathrm{CNY} 20,000$ at the time of signing the contract as a guarantee of the worker's performance. The deposit was to be given back at the end of the two-year working period. If the worker had breached the contract or caused damage to the employer, the deposit would not have been returned. ${ }^{30}$ In the present case, $\mathrm{CNY} 20,000$ was a considerable amount of money for a worker, roughly equivalent to four months' income. Many of the workers had had to take loans in order to pay for that. As was later revealed in journalistic interviews, the workers did not dare to resign from their work out of fear that they would not recover their deposit. The deposit system played a

29 See The International Labour Organization, Ratifications for Equatorial Guinea, $<\mathrm{www}$ .ilo.org/dyn/normlex/en/f?p=100o:11200:0::NO:1120o:P11200_COUNTRY_ID:103117>, visited on 6 June 2019.

$30 \quad$ This practice had already been prohibited by China in 2003. Before its abolition, taking a performance deposit was authorised by the then Ministry of Foreign Trade in 1997, to the extent that the amount should not exceed 20 per cent of a worker' overall salary. The Ministry of Commerce of the People's Republic of China, 财政部、商务部矢于取消对 外经济合作企业向外派劳务人员收取履约保证金的通知 (Circular of the Ministry of Finance and the Ministry of Commerce on Abolition of the Performance Deposit taken by Enterprises of Foreign Economic Cooperation from Workers Assigned Abroad) (2003). 
significant disciplinary role in the case of labour conflict. Workers carried out work under unfavourable working conditions to avoid monetary loss.

A third issue concerns working hours and holidays. The posted workers were posted to Equatorial Guinea for an agreed period of two years. During those two years, they were not to be given annual holiday. It was also reported that they had been working excessively long hours, ten hours a day on average. It seems no overtime pay was paid to the workers. ${ }^{31}$

Fourthly, health and safety at work were at stake. Equatorial Guinea is a country with a high risk of malaria transmission. ${ }^{32}$ The workers had constantly suffered from malaria and neither the employer nor the employment intermediary had fully disclosed the malaria risk to workers. No effective preventive measures had been implemented at the construction site against transmission of malaria. The workers' knowledge of malaria proved to be extremely poor, and they were exposed to a high risk of malarial infection. ${ }^{33}$ The workers were infected by mosquito bites, and suffered from painful symptoms such as high fever, vomiting and headaches. The company had equipped its own medical personnel on site to treat the workers. Once infected by malaria, the workers were forced to take a break from work. Because of infection from malaria, few workers were able to work throughout the month. The employer was unable to provide safe and healthy working conditions.

$31 \quad$ For employers who apply a piecework system, the Chinese Labour Law of 1994 requires them to set reasonable quotas of work and standards for piecework remuneration in accordance with the working hour system. It should not infringe the workers' right to rest. See Art. 37, 中华人民共和国劳动法 (Labour Law of the People's Republic of China) (1994).

32 "In 2015, it is estimated that 7 of the 43 countries in sub-Saharan Africa with malaria transmission had more than $25 \%$ of their population infected with malaria parasites (Burkina Faso, Cameroon, Equatorial Guinea, Guinea, Mali, Sierra Leone and Togo)". World Health Organization, World Malaria Report 2016 (2016), p. 45, <www.who.int/malaria/publications/world-malaria-report-2016/en/>, visited on 6 June 2019.

33 Upon the return of the workers, the Centre for Disease Control and Prevention of Donghai County conducted a medical examination for the 121 workers from Donghai. Ten workers were diagnosed as being infected by falciparum malaria. A recent study on Malaria infection in Jiangsu Province, to which Donghai County belongs, indicates that, from 20012011, 918 malaria cases were imported, mostly from African countries, with 146 cases from Equatorial Guinea. The research concludes that this is largely due to increased travel to Africa by Chinese nationals, in particular construction workers. See Y. Liu, M.S. Hsiang, W. Wang, Y. Cao, R. Gosling, J. Cao and Q. Gao, 'Malaria in Overseas Laborers Returning to China: An Analysis of Imported Malaria in Jiangsu Province 2001-2011', 13 Malaria Journal (2014) p. 29. 
Fifthly, collective labour rights were largely denied. The workers were denied democratic participation and governance at the workplace. No trade union or works council or other organ of workers representation was present or established. The management responded to workers' concerns in a dictatorial style. When concerns were voiced collectively by workers through their representatives, no sincere efforts to inform and consult, or negotiate and mediate, were tried on the management side. Additionally, the right to strike was violently denied.

\section{3}

\section{An Enclave of Legal Vacuum?}

It is useful to understand the living and working space of posted workers discussed as an enclave. The Chinese posted workers stayed in dormitories provided by their employer, with free food provided. Dormitories of this kind, often made of recyclable materials, are built next to the construction site. The site, together with the dormitory, is often segregated from the outside world by high walls, accessible only through guarded gates. The Chinese workers worked and lived within these walls. They rarely went out of the worksite, for various reasons such as the language barrier, the high price of local consumption, lack of time, and so on. The wall cut interaction between the workers and the local community to a minimum. As an enclave, the workplace was largely segregated and isolated from the local community, both spatially and socially. ${ }^{34}$

An enclave operates in the gaps of sovereigns. In accordance with wellestablished principles of international law, the state of origin of posted workers and its local embassy are prohibited from exercising administrative authority over the state's companies or posted workers in a foreign state. Acting otherwise would constitute an illegal intervention in the internal affairs of the host state. ${ }^{35}$ At the same time, the host state may have little interest in actual

34 It has been observed that in the EU posted workers face similar problems such as the language barrier, isolation of both the working and the living community, and anti-union pressure from the employer. See N. Lillie, 'The Right Not to Have Rights: Posted Worker Acquiescence and the European Union Labour Rights Framework', 17 Theoretical Inquiries in Law (2016) pp. 39-62. See also Caro et al., supra note 11.

35 Of course, the embassy and consular offices of a country can offer consular services to their nationals abroad as provided for in the 1961 Vienna Convention on Diplomatic Relations and the 1963 Vienna Convention on Consular Relations. Yet the exercise of consular protection cannot impede the sovereignty of a host state and should not interfere with the internal affairs of the host states. 
administration of enclaves due to the temporariness of the posted workers' presence, as long as they do not disturb local peace and security.

Posted workers are accessory to cross-border services in trade, and, as such, they are not legal subjects properly entitled to a full set of legal rights in the host country where they carry out work only on a temporary basis. ${ }^{36}$ This nonsubject status fits with the fact that posted workers are largely invisible and unknown in the daily life of the host state. Host state laws do not usually permeate into the internal operation of an enclave. As a consequence, the enclave organises itself largely as a self-constituting, semi-autonomous community with its own hierarchy, authority, governance structure, language and social life. In these circumstances, the management has a strong presence in the enclave and may act as a factual governor, whose authority over the workers is not limited to work-related matters based on the employment contract, but rather becomes omnipresent deriving from the power to administer the territory of the enclave. Access by the workers to the enclave depends upon the approval of and cooperation from the employer, as the authorities of the host state require an employment contract before issuing a visa to a foreign worker.

The subjection of workers to the management is a profound structural element of an enclave. If the essence of labour law is to rectify the advantageous position of the employer over workers through state intervention, the enclave presents itself as a legal vacuum in terms of labour protection. Even formally, the rights of posted workers are uncertain and vague, as the case under discussion demonstrates. Turning to the private international law perspective reveals the complexity of decision-making between different jurisdictions presupposed by the state-based system of jurisdiction and choice of law. Which jurisdiction would have been competent to handle the case? Which law would have governed the rights of the workers: Chinese law, or Equatorial Guinean law, or a mixture? What would have been the relevance of international labour conventions that both China and Equatorial Guinea have ratified? Similar questions arise about the relevance of the contents of the employment contracts. The management can easily set aside Chinese law for it is devoid of extraterritorial effect. If the law of the host country, namely Equatorial Guinean law, were applied, probably both the company and posted workers would be completely in the dark about its substantive content. In posting cases, legal uncertainty about workers' rights constitutes a part of daily operations. To formulate a claim to posted workers' rights immediately raises the question: on what legal basis?

${ }_{3} 6 \quad$ Liukkunen, supra note 4. 
Inside an enclave as such, no culture of workers' rights would develop. Instead, what is prevalent in the enclave is the managerial style of governance. An employment contract confers supervisory status on the employer - a status which, in the enclave, can transform and expand into a sovereign power of administration and enforcement. As a result, under such circumstances, the employment contract is enforceable against the employer only to the extent the employer voluntarily complies with it.

It is commonly highlighted that, in a cross-border context, workers are in a much weaker position than in the domestic setting due to the cross-border nature of the work. ${ }^{37}$ Typically, this asymmetry is sought to be corrected by particular private international law rules on jurisdiction and choice of law that are tailored to enhance weaker party protection. ${ }^{38}$ The habitual workplace of the worker is often given priority as an objective connective factor in choice of law. ${ }^{39}$ Yet, in posting cases, this does not guarantee sufficient protection and a more balanced approach has been sought from the application of the host state law, as the EU posted workers legal formula shows. Importantly, however, an enclave is an outlaw space to the extent that state laws do not easily affect normative practice inside the space.

\section{4}

\section{Resort to Strike: A Clash of Normativities}

In the case under study, internal disorder on the construction site spilled outside the walls and brought about a direct contestation between Chinese (labour) law and Equatorial Guinean (labour) law as soon as the Chinese workers went on strike. Through the presence of Chinese posted workers, the Chinese (labour) law framework interacted with and was also contested by the Equatorial Guinean (labour) law system on a daily basis.

37 See U. Liukkunen, The Role of Mandatory Rules in International Labour Law - A Comparative Study in the Conflict of Laws (Talentum, Helsinki, 2004) p. 7 .

38 See for example S.C. Symeonides, 'Result-Selectivism in Private International Law', 46 Willamette Law Review (2009) p. 1.

39 See U. Liukkunen, 'Introduction', in U. Liukkunen (ed.), Employment and Private International Law (Edward Elgar, Cheltenham, forthcoming 2020). See also generally J. Basedow, 'The Law of Open Societies - Private Ordering and Public Regulation of International Relations', in, The Hague Academy of International Law, Collected Courses of The Hague Academy of International Law - Recueil des cours Volume 360 (Brill, Nijhoff, 2013) p. 392. 
In the present case, the issue of the right to strike is a telling example. The 1991 Constitution of Equatorial Guinea in Article 10 recognises workers' right to strike, by qualifying its exercise in accordance with the law. ${ }^{40}$ However, the implementation law was never enacted and the country's labour code of 1990, as applied at the time of the clash in 2008, was silent on the matter of strikes. Neither authorisation nor regulation was established. Equatorial Guinea had been ruled authoritatively by President Teodoro Obiang Nguema Mbasogo since 1979 and the government operated a suppressive policy against strikes.

In China, the issue of strikes has remained deregulated. ${ }^{41}$ Chinese labour legislation is silent on the right to strike. Moreover, Chinese law does not stipulate any procedural requirements for the exercise of strike action either. The right to strike is legally neither permitted nor prohibited. Formally, no legal sanctions exist against strikers except in cases of deliberate destruction of property, or of disruption of public order. Workers are often not subject to claims in contract or tort purely because of a strike in China. Generally speaking, it is warranted to say that to a limited extent the right to strike is recognised in the form of customary law and natural justice in the Chinese legal order. ${ }^{42}$

In our case, Chinese posted workers sent to Equatorial Guinea tried spontaneously to resort to strike tactics to compel the employer to perform its contractual obligations. This is how collective exercise of labour rights was understood by the Chinese workers themselves in the enclave. Through calling on the involvement of local police, the management tried to suppress the strike action by selectively introducing local laws into the enclave. As Equatorial Guinean law prohibits unauthorised strikes, the workers would have needed to go back

40 Equatorial Guinea is a member of the ILO and has ratified all eight ILO core Conventions but has not provided protection for related fundamental rights at work, failing also to comply with the reporting system of the ILO.

41 China, as one of the founders of the ILO in 1919, has not ratified ILO Convention No 87 concerning freedom of association and protection of the right to organise. The Convention contains no express regulation on the right to strike but ILO supervisory bodies have considered the right to strike an intrinsic corollary of the right of association protected by the Convention. See The International Labour Organization, Freedom of Association - Digest of Decisions and Principles of the Freedom of Association Committee of the Governing Body of the ILO (5th revised edition, 2006) para. 523, <www.ilo.org/wcmsp5/groups/public/--ed_norm/---normes/documents/publication/wcms_090632.pdf>, visited on 6 June 2019. The question of the right to strike has been increasingly discussed amongst scholars and policy-makers in China. See A.C. Neal, 'Implementing I Io Fundamental Labour Rights in China: A Sensitive Meeting of Form and Substance?', in U. Liukkunen and Y. Chen (eds.), Fundamental Labour Rights in China - Legal Implementation and Cultural Logic, Ius Gentium: Comparative Perspectives on Law and Justice (Springer, Cham, 2016) pp. 19-65. 
to work. This constellation brought about a direct contestation between different conceptions and regimes of the right to strike under Chinese law and Equatorial Guinean law respectively. It can be argued that on this point, Chinese labour law extraterritorially interfaced with the law of the host state.

The selective introduction of local law by the management to challenge the workers' strike was seen as a means of suppression, leaving the workers profoundly irritated and disturbed. The workers considered this as a deprivation of their natural rights. To have the police forcibly enforce local law led to a direct confrontation between the police and the workers, between positive rules and what could be called natural justice. In the background stood a complex clash between China's deregulatory approach to strikes and the restrictive approach of Equatorial Guinea.

A clash of normativities is unlikely to be sufficiently addressed through the traditional regulatory approach of private international law. Bilateral conflicts rules presuppose that the applicable law, whose determination in the absence of a choice of law clause is based on the idea of the closest connection, can provide sufficient protection to the worker. ${ }^{43}$ However, it is largely acknowledged that such conflicts rules may not alone provide sufficient protection. For this reason, there are rules - as in the EU, for example - that restrict the effects of parties' choice of law by ensuring the application of mandatory rules of the law that would have been applicable in the absence of a choice of law. ${ }^{44}$ This kind of broader protective network of conflicts rules does not, however, extend to situations where the choice of law process does not even get started, or if it starts, where the outcome of choice of law does not guarantee sufficient substantive protection for workers. Moreover, collective labour disputes concerning the right to organise and the right to strike have their own choice of law rules. The complexity of legal conflicts in enclave governance is profound and requires rethinking the means of worker protection through private international law.

43 This kind of regulatory approach was used in Regulation (EC) No 593/2008 of the European Parliament and of the Council of 17 June 2008 on the law applicable to contractual obligations (Rome I). Also many non-EU countries, such as China, have adopted largely or to some extent similar kinds of bilateral conflicts rules on individual employment contracts.

44 For this kind of regulatory approach see Article 8(1) of the Rome I Regulation. The Regulation also enables an application of internationally mandatory rules of the lex fori, and, on certain conditions, of third countries. 
China's regulatory framework for cross-border posted workers started to take shape from the early 2000 in line with China's 'go global' strategy. With the growing number of overseas posted workers came an increasing number of labour incidents, putting much regulatory pressure on the Chinese government. In justifying its adoption of a ministerial rule specifically for overseas projects, the Chinese Ministry of Commerce has referred to examples of labour incidents such as sit-downs by workers in front of Chinese embassies and consulates, marching and demonstrating on the street, and clashes with local police: "The above incidents have not only affected the implementation of overseas contracted projects, but also caused damage to the overall image of Chinese enterprises, some of which even had an adverse impact on diplomatic relations and bilateral economic intercourse." 45 The rationale of the regulatory framework was designed with the aim of preventing and settling labour disputes and to ensure smooth international economic cooperation.

Regulatory attempts were taken by China to address overseas labour conflicts between dispatching companies and posted workers. Comprehensive regulation on cross-border posting of workers was promulgated by the Chinese Ministry of Commerce in 2006. ${ }^{46}$ Four specific measures were put into effect in order to strengthen the protection of posted workers. The first principle was a prohibition on outsourcing manpower. The general contractor may subcontract the project as a whole to subcontractors, but the workers are to be part of the projects and they are to sign an employment contract directly with the general contractor or subcontractors. The subcontractors are not allowed to further subcontract either the projects or their labour force to third parties. The general contractor undertakes overall responsibility for overseeing labour issues. Secondly, a reserve fund for international labour cooperation was extended to cover posted workers. General contractors and subcontractors are required to pay into the reserve fund, which will be used to pay for workers' remuneration, medical or rescue expenses, and other loss in case the contractors fail to pay for them. Thirdly, a more interventionist approach was taken towards employment contracts between employers and workers. Conclusion of an employment contract must stipulate on issues such as work assignment,

45 Ministry of Commerce of the People's Republic of China, 商务部矢于印发《对外 承包工程项下外派劳务管理暂行办法》的通知 (Notice of the Ministry of Commerce on Issuing Interim Measures Administration of Labour Service to Foreign Contracted Projects) (2006). 
place of work, duration of contract, remuneration, working days and hours, costs of international flights, local transportation, holiday and rest, overtime pay, working conditions, labour protection, accommodation and food, medical and social insurance, and other matters. ${ }^{47}$ The requirements set by the regulation are much more extensive compared to what is normally required for a an employment contract in a domestic setting. ${ }^{48}$ Fourthly, as for labour disputes and incidents, Chinese embassies and consulates abroad were required to act promptly and appropriately to safeguard the lawful interests and rights of workers and to avoid disputes escalating into diplomatic issues. In particular, Chinese companies should not obstruct workers from appealing to Chinese embassies and consulates about their grievances and concerns. ${ }^{49}$

In China, the incident of March 2008 in Equatorial Guinea quickly led to reinforced regulation of posted workers. An urgent notice was issued by the Chinese Ministry of Commerce with specific reference to the incident in Equatorial Guinea. ${ }^{50}$ In that notice, the Ministry urged the contractors to fulfil their obligations. The prohibition on taking any kind of performance deposit was reiterated. In addition, the notice set out that the wage arrangement should fully take into account exchange rate fluctuations. Particular advice was to adopt a fixed exchange rate or other measures to ensure that workers' actual income in Chinese yuan would not shrink. Moreover, training of posted workers before posting was emphasised. Workers were to be informed of local working and living conditions, and also educated to abide by local laws. In addition, the notice mandated immediate establishment of a dialogue mechanism among the four parties involved, i.e., representatives of posted workers, managerial personnel on site, and personnel from both the domestic headquarters and its overseas branches. This aimed to establish a more direct channel for preventing and

47 Ministry of Foreign Trade and Economic Cooperation of the People's Republic of China, 《矢于印发<劳务输出合同主要条款内容>的通知》(Notice on Printing and Distributing the Contents of the Main Provisions of the Labour Export Contract) (1996), $<$ www.mofcom.gov.cn/aarticle/subject/waipailaowu/subjecta/200612/20061204102621 .html $>$, visited on 9 June 2019 .

48 See Art. 19, 中华人民共和国劳动法 (Labour Law of the People's Republic of China) (1994); and Art. 17, 中华人民共和国劳动合同法 (Labour Contract Law of the People's Republic of China) (2007).

49 Ministry of Commerce of the People's Republic of China, supra note 45, Art. 16.

50 Ministry of Commerce of the People's Republic of China, 商务部矢于切实做好对 外承包工程项下外派劳务管理工作的紧急通知 (Urgent Notice of the Ministry of Commerce on Conscientiously Doing A Good Job in the Management of Expatriate Labour Under Foreign Contracted Projects) (2008), <www.mofcom.gov.cn/article/h/ redht/200805/20080505532327.shtml $>$, visited 9 June 2019 . 
resolving potential or actual disputes and to a certain extent might be considered also as a channel generating room for employee participation. Most of these regulations were further endorsed by the State Council in its Administrative Regulation on Contracting Foreign Projects adopted in July 2008.51

After long preparation, new Chinese statutory private international law rules were enacted in 2011 with the Law on Choice of Law for Foreign-related Civil Relationships. ${ }^{52}$ The conflicts rules on employment contracts were based on application of the law of the habitual workplace. In Article 43, the Law establishes a rule governing choice of law in employment contracts. Specifically, as for posted workers, the Law authorises application of the law of the place where the posting takes place. Yet it is unclear if and how this rule applies to cross-border posted workers. However, the Chinese regulation of 2006 discussed above gives a certain degree of recognition to the labour law of the host country and its relevance to the operation of posted workers' employment contracts. The contractors are required to sign employment contracts with posted workers in accordance with the labour law of the host country as well as relevant Chinese laws and regulations. ${ }^{53}$ The labour law of the host country is also acknowledged to have an informal role in guiding the conclusion and implementation of the employment contract.

Efforts to advance extraterritorial application of Chinese labour law to Chinese companies have been incremental but piecemeal and unilateral in nature, and, as such, they had clear limitations. On the one hand, it had to be moulded with great caution so as not to ignore the sovereignty of local laws. ${ }^{54}$ On the other hand, it should be noted that implementation of Chinese regulations was carried out through voluntary, educational and mediatory means alone. Despite these regulatory efforts, overseas labour incidents have continued to break out, albeit on a somewhat smaller scale. With the evident limitations of a unilateral regulatory approach, the essential question remains how and to what extent posted workers' rights might be recognised and enforced in a transnational context.

$5^{1}$ State Council of the People's Republic of China, 对外承包工程管理条例 (Administrative Regulation on Contracting Foreign Projects) (2008), revised on 1 March 2017.

$5^{2}$ Standing Committee of the National People's Congress of the People's Republic of China, 涉外民事矢系法律适用法 (Law on Choice of Law for Foreign-related Civil Relationships) (2010).

53 Ministry of Commerce of the People's Republic of China, supra note $5^{0 .}$

54 See K. Van Wezel Stone, 'Labor and the Global Economy: Four Approaches to Transnational Labor Regulation', 16 The Michigan Journal of International Law (1995) p. 1026. 
A stateless regulatory territory which formally exists within a state is difficult to intervene in. The question of enclave governance reveals the absence of law and legal protection in enclaves where state actors remain distant. The level of development of the state naturally affects the status of labour rights and labour protection that an individual state can provide. It is equally true that labour law systems require additional external conditions for their development and operation. ${ }^{55}$ Besides having a humanitarian face, labour protection is amenable to being conceptualised as a prominent political issue, the characterisation of which hinges upon the context of its operation. ${ }^{56}$ Temporary enclaves also exist in developed countries, resulting in the rights of posted workers being formally entitled, largely invisible and practically inaccessible. ${ }^{57}$ Not only the mobility of the workers but also the mobility of their enclaves - each being connected to the temporary nature of both the work and the enclaves in the host country - contribute to the vulnerability and invisibility of workers' situation.

The traditional approach to compliance with international labour standards is largely ratification-centred. ${ }^{58}$ This approach builds on the classic understanding of the power relationship between employers and employees. ${ }^{59}$

The traditional system of international labour standards presupposes that, via a state-bound regulatory scheme, norms are transformed into obligations

55 S. Deakin, 'The Contribution of Labour Law to Economic and Human Development', in G. Davidov and B. Langille (eds.), The Idea of Labour Law (Oxford University Press, Oxford, 2011) p. 168.

56 Y. Chen, 'ILO, Extraterritoriality and Labour Protection in Republican Shanghai', in U. Liukkunen and Y. Chen (eds.), Fundamental Labour Rights in China: Legal Implementation and Cultural Logic Ius Gentium: Comparative Perspectives on Law and Justice (Springer, Cham, 2016) p. 83.

57 See for example Caro et al., supra note 11; I. Wagner and L. Berntsen, 'Restricted Rights: Obstacles in Enforcing the Labour Rights of Mobile EU Workers in the German Construction Sector', 22 Transfer: European Review of Labour Research (2016) pp. 193-206.

$5^{8}$ A state-centred model of responsibility has been an underlying premise of the work of the ILo. See also Y. Dahan, H. Lerner and F. Milman-Sivan, 'The International Labour Organization, Multinational Enterprises, and Shifting Conceptions of Responsibility in the Global Economy', in A. Marx, J. Wouters, G. Rayp and L. Beke (eds.), Global Governance of Labour Rights. Assessing the Effectiveness of Transnational Public and Private Policy Initiatives (Edward Elgar, Cheltenham, 2015) pp. 278-305 and L. Baccini and M. KoenigArchibugi, 'Why Do States Commit to International Labor Standards? Interdependent Ratification of Core ILo Conventions, 1948-2009', 66 World Politics (2014) pp. 446-49o.

O. Kahn-Freund, Labour and the Law (Stevens, London, 1972) p. 6. 
which can be imposed on employers and rights which can be conferred on employees. ${ }^{60}$ However, this system fails to recognise the problem of enclave governance lurking behind global business practices as it shies away from the question of accessibility of state sovereignty in a transnational setting. ${ }^{61}$ To some extent, soft law in its various forms has filled legal vacuums that occur in a cross-border setting, but this has had very little influence on actual crossborder employment practices. Posting enclaves have remained largely immune from influences external to enclaves.

There is much well-deserved criticism that changes in regulatory approaches - reflected by the various sets of non-binding rules in non-state public and private initiatives - strengthen the position of the market and weaken the role of national legislators. Soft law-based approaches highlight voluntarism and, as such, lack efficiency. ${ }^{62}$ Nevertheless, labour governance via non-state regulation has been hailed as a step in the right direction, albeit not without controversy, when the point of departure is promoting a commitment to ILO fundamental principles and rights at work as defined by the ILO in 1998. Strikingly, ILO fundamental principles and rights at work have not assumed an important role in corporate codes of conduct although the Declaration of 1988 originates in the ILO core conventions, which thus form what is advanced as the core of today's international labour standards. ${ }^{63}$ In the global era, a counterforce to economic actors is not sought from strengthening the position of international labour standards in the ILO member states, but from a soft law approach with multiple non-binding regulatory patterns. ${ }^{64}$

This has also meant that the fundamental rights agenda has become blurred, with various soft law regulatory initiatives side-lining essential aspects of protection that would require attention in posting cases. Reasons for poor enforcement of international labour standards can be sought from several

6o On the impact of the tripartite nature of the ILO see e.g., N. Valticos and G. von Potobsky, International Labor Law (Kluwer Law and Taxation, Deventer, 1995) pp. 33-40.

61 See F. Hendrickx, 'Beyond Viking and Laval: The Evolving European Context', ${ }_{2}^{2}$ Comparative Labour Law \& Pol'y Journal (2011) p. 1077.

62 J. Klabbers, 'The Redundancy of Soft Law', 65 Nordic Journal of International Law (1996) p. 167.

63 U. Liukkunen, 'Transnational Labour Law and Fundamental Labour Rights: Making Chinese Workers Matter?', in U. Liukkunen and Y. Chen (eds.), China and ILo Fundamental Principles and Rights in Work (Kluwer Law International, Alphen aan den Rijn, 2014) pp. 163-180.

64 See J. Klabbers, 'Marginalized International Organizations: Three Hypotheses Concerning the ILO', in Liukkunen and Chen (eds.), ibid., pp. 187-196. 
sources. But we also need to ask more seriously: what is the core content of protection to be sought? As the Chinese posting case demonstrates, health and safety at work are of utmost importance and should be guaranteed at the fundamental labour rights level. ${ }^{65}$ On the other hand, as we have argued elsewhere, the approach of singling out and focusing in particular on 'fundamental' labour rights may already have distorted identification of the transnational labour question involved in the first place. That approach may fail to give an authentic voice and interpretation to the labour question in its entirety by prioritising certain issues and values over other alternatives, by excluding certain matters from investigation, or by qualifying usable vocabularies of discourse. ${ }^{66}$ A solution to the transnational labour question to be sought depends on epitomising and formulating the question.

\section{From International to Transnational: Towards Transnational Labour Law}

The case of posted workers highlights challenges that economic globalisation has posed to labour law in terms of how to conceptualise labour protection. Labour protection has been an issue deeply embedded within a sovereign framework. Indeed, the failure of both unilateral and multilateral approaches has much to do with their sovereign-centred framework. The issue of labour protection was born from the sovereign experience of intervention in industrial relations. Moreover, engagement with labour protection in many countries was also an integral part of the state-building process. International labour law, developed by and around the ILO, reproduces and reinforces the sovereign paradigm of labour protection. However, globalisation has presented two acute regulatory challenges to traditional regulatory assumptions: firstly, the absence of global sovereignty and, secondly, deterritorialisation. ${ }^{67}$ In other words, the need for labour protection repeatedly occurs in transnational space where traditional sovereign authority is vague and distant.

65 The most important related ILO Conventions are No. 155 on Occupational Safety and Health; No. 161 on Occupational Health Services and No. 81 on Labour Inspection.

66 U. Liukkunen and Y. Chen, 'Developing Fundamental Labour Rights in China - A New Approach to Implementation', in U. Liukkunen and Y. Chen (eds.), Fundamental Labour Rights in China - Legal Implementation and Cultural Logic (Springer, Cham, 2016) p. 3.

67 On the need for de-territorialisation of domestically-oriented labour law, see G. Mundlak, 'De-Territorializing Labor Law', 3 Law \& Ethics of Human Rights (2009) p. 188. 
Posting as a cross-border employment practice reveals the vulnerability of domestically oriented labour law and the inaccessibility of protection it can offer. The shift of regulatory power that is visible in posting enclaves relates to complex normativities that occur in a transnational setting. Broadening the sphere of soft law as a labour rights regulatory tool is advanced by the fact that the regulatory systems which states are built upon have remained underdeveloped in terms of meeting transnational challenges posed to law. This can be seen in the striking distance between international law and private international law, and in the debate over transnational law being too often limited to identifying cross-border transactions, without any real grasp of the nature of the normative setting of 'transnational' that exists. ${ }^{68}$

Against this background, we advocate a new research perspective for transnational labour law. ${ }^{69}$ The concept of transnational labour law may be broadly understood as principles, rules, procedures and mechanisms that function to recognise and enforce labour standards in a transnational setting. ${ }^{70}$ The concept also refers to processes of transnationalisation of norms and normativities. Especially de-nationalisation and de-territorialisation of labour law standards is characteristic of transnational labour law, which distances normsetting from traditional state-bound contexts - for instance via international framework agreements and different kinds of public and private codes of conduct. ${ }^{71}$ The aim is to explore and theorise the normative and regulatory elements of labour law in transnational space. These elements relate to the ongoing evolution of the labour question in a transnational setting. As an intellectual effort, transnational labour law looks into the possibilities and limits of labour protection beyond the traditional paradigm of national and international labour standards. This also allows a refreshed and systemic examination

68 Liukkunen, supra note 63.

69 The idea of transnational labour law has been proposed and advanced by various scholars in different contexts. See e.g., Van Wezel Stone, supra note 54, p. 987; D.M. Trubek, J. Mosher and J.S. Rothstein, 'Transnationalism in the Regulation of Labor Relations: International Regimes and Transnational Advocacy Networks', 25 Law \& Social Inquiry (2000) pp. 1187-1211; A. Ojeda-Avilés, Transnational Labour Law (Kluwer Law International, Alphen aan den Rijn, 2015); see also A. Blackett and A. Trebilcock (eds.), Research Handbook on Transnational Labour Law (Edward Elgar, Cheltenham, 2015).

70 B. Burkett, 'The International Labour Dimension: Introduction', in J.D.R. Craig and S.M. Lynk (eds.), Globalization and the Future of Labour Law (Cambridge University Press, Cambridge, 2006) pp. 15-50.

71 See also supra note 67. 
of the labour clause stipulated in free trade agreements, ${ }^{72}$ labour standards incorporated by international financial institutions and labour practices committed to by multinational enterprises in their corporate social responsibility strategies. In the case of posting, the transnational labour law perspective examines not only national labour laws, but also the congruence of public and private international law, as well as the role of private actors as de facto enforcing agencies of labour standards.

However, transnational labour law does not function to replace existing national or international labour regulations. Instead, it largely builds on existing normative systems of labour standards. It works to supplement - but also to compete with - existing regulatory frameworks. The emergence of transnational labour law does not involve a denial of the relevance of national and international labour law regimes in regulating work in the global economy. Rather, it should be seen from the perspective of reconceptualising existing normative regimes in the light of an underpinning transnationality and sketching the architecture for the normative edifice of transnational labour protection.

The notion of enclave governance provides an important addition to the existing literature on transnational labour law. This literature discusses issues such as the deterritorialisation of labour law and the extraterritorial dimension of national labour law, ${ }^{73}$ the impact of trade arrangements or financial institutions on labour protection, ${ }^{74}$ private enforcement of international framework agreements, ${ }^{75}$ or the application of labour standards to supply chains by multinational enterprises. ${ }^{76}$ This move from states/territoriality to

72 See B. Hepple, Labour Laws and Global Trade (Hart Publishing, Oxford, 2005).

73 See S. Charnovitz, 'The U.S. International Labor Relations Act', 26 ABA Journal of Labor \& Employment Law (2011) pp. 311-325; P. Macklem, 'Labour Law Beyond Borders', 5 Journal of International Economic Law (2002) pp. 621-631.

74 See C. Kaufmann, Globalisation and Labour Rights: The Conflict between Core Labour Rights and International Economic Law (Hart Publishing, Oxford, 2007); F. C. Ebert, 'International Financial Institutions' Approaches to Labour Law: The Case of the International Monetary Fund', in Blackett and Trebilcock (eds.), supra note 69, pp. 124-137.

75 See R.-C. Drouin, 'Promoting Fundamental Labor Rights through International Framework Agreements: Practical Outcomes and Present Challenges', ${ }_{31}^{1}$ Comp. Lab. L. \& Pol'y J. (2010) pp. 591-636.

76 See for example, H. Arthurs, 'Reinventing Labor Law for the Global Economy: The Benjamin Aaron Lecture', 22 Berkeley Journal of Employment and Labor Law (2001) pp. 271-294; R.M. Locke, The Promise and Limits of Private Power: Promoting Labour Standards in a Global Economy (Cambridge University Press, Cambridge, 2013). 
actors/authority has much merit in it. ${ }^{77}$ However, this case study highlights the possibility and importance of uncovering the transnational labour dimension within a sovereign territory. It emphasises the spatial dimension of labour law standards implementation in certain concrete settings that are acute and significant to enhancing labour protection and preventing new vulnerabilities in a transnational setting. It further points to the possibility of looking at substate sites as important loci for transnational labour law research.

From the perspective of transnational labour law, the example of enclave governance provides additional insights: the transnational legal context calls for a wider normative framework where the intersections between labour law, public international law and private international law are taken seriously. ${ }^{78}$ The operation of private international law rules on jurisdiction and choice of law concerning individual employment contracts is not neutral in terms of the outcome. However, posting cases demonstrate that weaker party protection requires further strengthening at the international level. Conflicts rules should enable protection of the fundamental rights of posted workers regardless of the applicable law (lex causae), and the normative basis for this should derive more directly from international law. ${ }^{79}$ The fundamental labour rights approach has already brought the language of international human rights into labour protection discourse. ${ }^{80}$ It might be useful to strengthen the connection between international law and private international law through identifying certain directly applicable rules (lois de police) in private international law. ${ }^{81}$

77 See Liukkunen, supra note 39.

78 See Liukkunen, supra note 63.

79 See P. Kinsch, 'The Impact of Human Rights on the Application of Foreign Law and on the Recognition of Foreign Judgments - A Survey of the Cases Decided by the European Human Rights Institutions', in T. Einhorn and K. Siehr (eds.), Intercontinental Cooperation Through Private International Law. Essays in Memory of Peter E. Nygh (T.M.C Asser Press, The Hague, 2004).

8o $\quad$ Liukkunen \& Chen, supra note 66, p. 13.

81 In private international law, directly applicable rules, or internationally mandatory rules, are referred to under different terms, such as lois de police or lois d'application immediate. On the nature and purpose of internationally mandatory rules, see e.g., T.C. Hartley, 'Mandatory Rules in International Contracts: The Common Law Approach', in The Hague Academy of International Law, Collected Courses of The Hague Academy of International Law - Recueil des cours Volume 266 (Brill, Nijhoff, 1997) pp. 345-348; T. C. Hartley, 'The Modern Approach to Private International Law: International Litigation and Transactions from a Common-Law Perspective', in The Hague Academy of International Law, Collected Courses of The Hague Academy of International Law - Recueil des cours Volume 319 (Brill, Nijhoff, 2006) pp. 240-242; Basedow, supra note 39, pp. 429-450; Liukkunen, supra note 
Identifying directly applicable rules, which are applied irrespective of the applicable law, could be grounded on international labour standards based on a comparative study of national labour protection and its deficits as well as core labour standards and central ILO conventions together with other relevant international human rights instruments. ${ }^{82}$ It might also be useful to adopt certain minimum labour standards at the international level specifically for posted workers. These documents would be useful to multinational enterprises as well as national adjudicators and other regulators in the global arena.

Promoting protection of workers' human rights has little impact unless enforcement of those rights is considered as an essential element in their materialisation. ${ }^{83}$ The idea of transnational labour law calls for changing our focus from regulatory competence de jure to de facto regulatory power in setting and implementing labour standards when a sovereign authority is absent, diluted or prevented. As globalisation deepens, a growing number of actors, such as multinational enterprises, international and national associations of employers and workers, makers of regional and bilateral investment arrangements as well as international financial institutions are capable of transnational mobility and actions with significant labour ramifications. It is essential to develop a better understanding of how labour standards may be formulated and enforced in a rights-based manner in a transnational setting so that the pluralism of transnational actors is taken seriously.

In essence, transnational labour law should aim to reinvigorate the subjectivity of workers in international economic cooperation. ${ }^{84}$ Labour protection is often assimilated to and largely invisible in cross-border provision of services, enlargement of free trade, and liberalisation of investments. ${ }^{85}$ The normative project of transnational labour law aims at emphasising the

37, pp. 128-146; P. Nygh, Autonomy in International Contracts (Clarendon Press, Oxford, 1999), pp. 230-234.

82 See V.A. Leary, International Labour Conventions and National Law: The Effectiveness of the Automatic Incorporation of Treaties in National Legal Systems (Martinus Nijhoff Publishers, The Hague, 1982).

83 U. Liukkunen, 'ILO and Child Labour Regulation in China - Prospects and Complexities', in U. Liukkunen and Y. Chen (eds.), Fundamental Labour Rights in China - Legal Implementation and Cultural Logic, Ius Gentium: Comparative Perspectives on Law and Justice (Springer, Cham, 2016) p. 16o.

84 See Kaufmann, supra note 74.

85 D.M Trubek, 'The Emergence of Transnational Labor Law', 100 American Journal of International Law (2006) pp. 725-733; see also Arthurs, supra note 76, pp. 271, 292. 
central role of workers in international economic cooperation and global governance as well as giving a credible normative expression to the subjectivity of workers. ${ }^{86}$ Global protection of posted workers should be a featured project on the transnational labour law agenda.

86 Cf. ILO, Fair Migration: Setting an ILO agenda (2017) p. 7. 